\title{
Universiteit
}

Leiden

The Netherlands

\section{The religion of the Achaemenid rulers}

Jong, A.F. de; Jacobs, B.; Rollinger, R.

\section{Citation}

Jong, A. F. de. (2021). The religion of the Achaemenid rulers. In B. Jacobs \& R. Rollinger (Eds.), Blackwell Companions to the Ancient World (pp.

1199-1209). Hoboken, NJ: Wiley Blackwell. Retrieved from https://hdl.handle.net/1887/3256548

Version:

License:

Downloaded from:
Publisher's Version

Licensed under Article 25fa Copyright Act/Law

(Amendment Taverne)

https://hdl.handle.net/1887/3256548

Note: To cite this publication please use the final published version (if applicable). 
SECTION IX

\section{RELIGION AND WORSHIP}




\title{
CHAPTER 83
}

\section{The Religion of the Achaemenid Rulers}

\author{
Albert de Jong
}

According to Herodotus (Histories 3.31), the second Achaemenid king, Cambyses, had an ardent wish to marry his sister. Since such a marriage was not customary among the Persians, he asked the royal judges whether there were laws against it. The judges obliged him with a legal trick: they could find no law permitting a man to marry his sister, but they did find one that stated that the king of the Persians could do whatever he wished. Thus emboldened, the king married not one, but eventually two of his full sisters.

This episode is obviously part of the notorious narrative cycle on the life and deeds of Cambyses, which (especially in the case of Herodotus, our chief source) was designed to cast the king in the role of an irresponsible sacrilegious madman (a reputation that seems to have stuck). It has always been tempting, therefore, to explain the story of Cambyses' wedding preferences as part of this heated propaganda campaign, but some scholars have taken it more seriously and have sought to provide it with an appropriate historical context. Some have pointed at the example of the Egyptian pharaohs, who contracted marriages between full brothers and sisters, and saw Cambyses' wish in the light of a mimetic act in the context of claiming the Egyptian throne. Others have, more predictably, interpreted them on the background of the Zoroastrian tradition, according to which marriages within the close family are considered meritorious.

Although there is general agreement that the sources are too meager for any conclusion to be reached, these different strategies of interpretation are a good entry into the subject of this chapter: the religion of the Achaemenid

A Companion to the Achaemenid Persian Empire, Volume II, First Edition.

Edited by Bruno Jacobs and Robert Rollinger.

(C) 2021 John Wiley \& Sons, Inc. Published 2021 by John Wiley \& Sons, Inc. 
rulers. For this subject, too, source materials are meager and fractious and interpretations have varied widely, but within two easily recognizable patterns. Some scholars have assembled, from narrative and documentary sources, all evidence for the practice of religion in the Achaemenid Empire (especially in a court context), have resisted the urge to interpret them in the light of "fixed" (but largely assumed) religious patterns, and simply presented them as a faithful reflection of the religious life at court (Nagel and Jacobs 1989). Others have started from the opposite side of the spectrum, by invoking the notion of a Zoroastrian "tradition" to which the kings would have "belonged," which they "followed," and which can (or must) be used to analyze and explain the evidence. The former approach has the merit of avoiding anachronistic interpretations, but has forsaken even the attempt to distinguish fact from fiction, even in contexts (such as, for example, Xenophon's Cyropaedia) that appear to belong more to the realm of literary imagination. The latter procedure has the merit of giving direction to the question at hand - by fitting the evidence in longue durée patterns of the development of Iranian religion - but is often normative and anachronistic in placing reliance on a version of Zoroastrianism that is known to have taken shape only in the Sasanian period.

One of the chief instruments applied by scholars to avoid the extremes in these two positions is that of restricting scholarly attention to what are perceived to be "primary" sources: the Achaemenid royal inscriptions, the documentary evidence in Aramaic, the Elamite administration from the reign of Darius I, and the evidence of archeology. Many of these sources have little to say about religion, let alone about the religion of the Achaemenid rulers, so that the problem of finding a norm by which to judge and interpret the evidence remains.

To solve that particular problem, recourse is often taken to the evidence that has survived in Avestan, since the Avestan texts are considered to pre-date the rise of the Achaemenids (Knäpper 2011). That latter argument is, however, not unproblematic, since there is very little evidence to show the presence of texts in Avestan at the court of the Achaemenids, and almost no information on the question what people did with Avestan texts, with the exception of their (obvious) use in ritual contexts. There are, however, two tiny clues that could support the notion that Avestan texts were, indeed, present and used/ understood at the Achaemenid court. The first comes from the throne names of various Achaemenid kings (Darius, Xerxes, Artaxerxes, etc.), which are believed to make deliberate reference to passages or concepts from the Gathas (and which would, therefore, not only show the presence, but also the understanding of these Avestan texts; Schmitt 1982; Kellens 2002: pp. 422-434; and see Skjaervø 1999, 2012: pp. 12-15, for the broader notion of the presence of "Avestan" at the Achaemenid court). The second clue is the names of various deities and that of the first mythical ruler, mentioned either in the 
inscriptions or on the Persepolis tablets: four of these names (Auramazdā, Išpandaramattiš, Irdanapirrurtiš, and Iamakšeda) show a characteristic pattern of joining up as one name what in Avestan are more or less mobile collocations of "name" and "epithet" (or rather "noun" and "adjective"). This strongly suggests that by the time of their being recorded in Achaemenid Parsa, these had become set names that were no longer understood or considered to consist of two separate (and understandable) words (de Jong 2015: p. 88). In this way, the presence and even use of Avestan (the defining characteristic of Zoroastrianism) can be demonstrated for the Achaemenid rulers (Kellens 2012).

There are, however, serious limitations to what can thus be known. The presence of individual (currently known) Avestan texts must remain uncertain, and so should the use of (currently known) Avestan texts as a normative source that demands to be followed, consulted, or believed. Such a normative role for Avestan texts is demonstrable only for the period after the writing down of the Avesta (the sixth century CE). Whatever we can reconstruct of earlier uses of religious literature strongly suggests that priests transmitted a body of traditions in the vernacular, alongside the liturgical texts in Avestan, and that it was this literature of tradition that formed the basis of the development of the religion - and acted as a shield for the majesty, stability, and nontemporality of the liturgy.

\section{Three Styles of Religion at the Achaemenid Court}

The present chapter does not aim to give an overview of "religion" in the Achaemenid Empire, but seeks to explore and discuss the evidence for the religion of the Achaemenid rulers. This subject has often been claimed to be fruitless, or its goal impossible to achieve, for lack of evidence (and historical relevance; de Jong 2015). The case may not be as grim as that, however, but it is important to make some of the limitations of the subject explicit. We have no instruments with which to measure "piety" or "devotion" or any other index of religious intensity. The chief reason for this is not just a dearth of evidence, but especially the institution of Achaemenid kingship itself. There is a firm distinction in most ideologies of kingship between the king as person and the king as institution. It is the latter, institutional, face of the king we get to see in all the non-literary surviving evidence, which does not allow of expressions of any emotion. This is made clear, programmatically, in several of the inscriptions of Darius. Many people show fear in DB, but not the king - he acts upon the fear of his people, and removes the obstacles in their (and his) way. When he outlines for posterity the qualities he, as the ideal king, possesses, these include not only physical abilities and unswerving support of 
justice and peace, but also mental self-restraint (DNb 11-15). The intimate interconnections made in all inscriptions between the king's activities and the support of Auramazda belong to a vocabulary of divine support and of royal success, not to one of piety. It is interesting to contrast this self-representation with the (equally idealized) sentimental Cyrus one encounters in Xenophon's Cyropedia, but even there, amidst Cyrus' weeping and laughter, religion rarely arouses the king's emotions.

In order to come to terms with the scantiness of the evidence, and to move beyond the fact that the evidence tends to show us the "king as institution" alone, it may be useful to distinguish three "styles" of religion for the Achaemenid rulers: the imperial, the familial, and the dynastic style. The focus of the imperial style is the empire itself, with its ideological underpinnings and the attempts to make religion sustain the (Iranian parts of) the Empire. The focus of the familial style is the privacy of the king as person and of his family. The dynastic style is somewhere in between the other two styles: its focus is the royal family, both as a "family" and as the central focus of the "empire."

It is important to stress that these different styles are heuristic devices only: they do not represent different "varieties" of religion that would be recognized by those whom it concerned themselves. They are, so to speak, different lenses that enable us to see the constraints put on the expression of religion or religiosity in the royal family. Their chief aim is to restore to the Achaemenids two unavoidable aspects of (any) religion: variance and agency. Variance can, of course, manifest itself historically, socially, and regionally (i.e. in historical developments, in different manifestations of religiosity among the various social layers, and in regional pluralisms), and the question should therefore be if there are patterned variations in the manifestation of religion that can be explained. Agency, the active involvement of the kings in the development of "their" religion, is one of the possible explanations, but it is never the only one. We shall see that especially the inclusion of (purportedly) "foreign" elements in the "Iranian" religion of the Achaemenids finds a more natural interpretation if we work with the lenses afforded by these different styles of religion.

\section{The Imperial Style of Religion Among the Achaemenids}

The imperial style of Achaemenid religion is the most strongly discursive expression of the three styles. It manifests itself chiefly in three unequally documented (or evidence-based) domains: the first of these is the (muchdiscussed) dossier of the royal inscriptions, art and archeology, and their use of religious or religiously-based language, material culture, and imagery. 
The second domain in which this imperial style may be traced is in the role the king played in the maintenance and support of religious observances that did not belong to his family traditions, but which came with the reality of the empire: the assumption, that is, of ritual responsibilities that were essential for the practice of kingship in (some of) the conquered, or included, territories of the empire. The third domain is much more hypothetical than the other two: it is rooted in the ex post facto realization that the Achaemenid Empire actively transformed the Zoroastrian religion, presumably in a deliberate imperial programme of streamlining (some) expressions of the Iranian religion.

\section{The Achaemenid Kings Speaking About Their Religion}

None of the royal Achaemenid inscriptions is actually about religion, but religious language is a very prominent part of many of these royal declarations. In some respects, the prominence of religious language in these texts makes them stand apart from their chief models, the royal declarations of other Near Eastern kings, who tend to speak of gods, rituals, and other aspects of religion chiefly when religion is the actual subject of their inscriptions (e.g. in dedicating temples). This can be connected with the absence of an institutionalized temple-cult in at least the earlier periods of the Achaemenid Empire. This absence seems to have sponsored the notion of the royal court as an imposing place of religious activity: whereas in the neighboring traditions, the king had to go to a specific place to fulfill his religious duties, in the case of the Achaemenids the court seems to have developed into a chief locus of imperial religion (de Jong 2010).

The overriding theme of the religious elements in the royal inscriptions is that of the king as maintainer, defender, and strengthener of order. This is done, chiefly, by recounting the fact that the royal god Auramazda, had (in the beginning) performed the same acts, with the same goal, and by pushing the parallels between royal and divine activities almost to their logical boundaries. The frequent protestations that the king could achieve all he had done only through the support of Auramazda add and stress the requisite temporal or humble nature of the king's program, compared to that of Auramazda, but mainly achieve what the king no doubt wanted to underline: the notion that the forging of the empire, its maintenance, growth, and esthetic embellishment, are terrestrial reflections of the creative act of the main deity (Lincoln 2012). This program is visible most clearly in the inscriptions of Darius, which seem to have established a model for his successors, and even though in the inscriptions of Xerxes and later kings variations can be found, these generally do not rise to the level that they would actively contradict this basic pattern. Alongside the importance of these declarations for a proper understanding of Achaemenid kingship and its ideology, it is likely that the way royal activity 
was modeled on the notion of repeating or continuing Auramazda's act of creation and support for order has itself been a major factor in the development of the interpretation of Auramazda's role in Zoroastrian theology: he basically became king of heaven, and thus acquired a role that is not traceable for him in earlier texts (but is attested abundantly in all later Zoroastrian literature). Thus, we end up with the paradox that the kings claim to mimic the activities of their god, but that in reality their god increasingly came to be seen in the image of the earthly kings.

The Achaemenid kings were the rulers of a vast territory and of numerous peoples with their own characteristic cultures and religions. Some of these - Elam, Babylonia, Egypt - were not only the bearers of much older civilizations, but also the chief models that gave the kings of the Persians the building blocks for the creation of an international dynastic style. It is not surprising, therefore, that in some of these contexts, the kings of the Persians continued the religious roles that came with their job as rulers of newly conquered lands. This development is strikingly parallel to their maintenance, up to a point, of other social institutions in these lands, especially administrative practices. Thus, Cyrus the Great, of whose religious beliefs we know next to nothing, is presented (in the Cyrus Cylinder) as the restorer of destroyed Babylonian sanctuaries and the king whom Marduk loved; in turn, Cyrus himself expresses the wish to worship Marduk every day. In the Hebrew Bible, of course, he is the anointed chosen by God to restore Israel, rebuild Jerusalem and the House of God in that city (Is. 45; Ez. 1), which he does - according to Cyrus' words in the Ezra narrative - because the God of Israel told him to do so. Likewise, in Egypt there are traces of Achaemenid kings absorbing religious titles of the Egyptian kings they had replaced by conquering the land. None of this is in the least surprising, but the collective evidence of Persian kings thus living up to local expectations may throw some light on the most extensive dossier on royal patronage of religion that has survived: the Elamite administration from the reign of Darius I (Henkelman 2008). This enormous amount of documentary evidence has been the source of much confusion and frustration, chiefly because scholars attempted to press the evidence into preconceived notions of religious and cultural purity of lineage. An Iranian king (or a Zoroastrian king) could not, it was assumed, spend his wealth on the worship of "foreign" (in this case, Elamite) gods, or in the maintenance of priests who served them. And yet the evidence for this support and this maintenance is incontrovertible: a not negligible portion of the revenue of the central areas of the Achaemenid Empire went to ritual acts in honor of a wide assortment of deities, many of them Elamite, following (it must be presumed) Elamite custom and performed by Elamite religious specialists. There is evidence, it is true, for "Iranian" religious specialists, too, and the case has been made that all the evidence together supports the idea of a local, "Persian," 
religious complex largely of Elamite origin, with an influx of Iranian divine names and practices (Henkelman 2008). The obvious discrepancy between this type of documentary evidence and the very strong focus on Auramazda (and Auramazda alone) in (most of) the Old Persian inscriptions strongly suggests the differentiation that can be traced in similar manifestations of the imperial style of Achaemenid religion.

This is all the more the case in light of the final element to be discussed for this imperial version of religion: the obvious efforts the kings made for the streamlining of the Iranian religion, which has had lasting effects on the development of Zoroastrianism. Through the creation of a calendar to unify Zoroastrian observance, and through the (eventual) genesis of royal fires, firetemples, and an organized priesthood (the evidence for which emerges only after the Achaemenid period, but in striking harmony with the notion that it must be a legacy of the Achaemenids), the Achaemenids obviously attempted to create a more coherent version of their own religion that would sustain their hold on the Iranian parts of the empire. The evidence for most of these developments - which also include a restructuring of the story of creation and the end of time, retold in terms of a 9000-year pact between the two spirits, a novel interpretation of the judgment of the soul, and a reinterpretation of the festival celebrated for the new year - the Achaemenids can be shown to have had a lasting impact on the development of Zoroastrianism (de Jong 2016). The importance of this gains relief from the fact that their (slightly distant) successors, the Parthians, are not known to have followed this imperial style of religion at all; there is no evidence for their use of religion as an element of culture that would sustain the empire. But the evidence, meager as it is, for the practice of Zoroastrianism in the Parthian empire clearly shows that some of the institutions the Achaemenids set up as part of this imperial style of their religion survived them.

\section{The Familial Style of Religion Among the Achaemenids}

Throughout its very long history, the family and the rites associated with the family have traditionally been seen as the mainstay or backbone of Zoroastrianism. This is particularly true, of course, of the history of Zoroastrianism after the Arab conquests, as a minority religion that had to eke out an existence among an ocean of Muslims and Hindus. In view of the difficulties in the source materials outlined above, which imply that those aspects of royalty we get to see belong more to the "king as institution" than to "the king as person," the evidence for family practice is virtually non-existent. The private lives of kings are known to us chiefly from romantic retellings 
that have been preserved in Greek - alongside similarly idealized representations of, for example, Achaemenid practices of education. It is important, however, to keep family aspects of the religion on the horizon of any discussion of the history of Iranian religions. In this particular case, its importance may chiefly be the fact that it is this version of Zoroastrianism - a religion practiced at home, served by family priests - that appears to have been the central practice of the religion among the Arsacids (Boyce and De Jong forthcoming). All evidence we have for the Achaemenids, however, belongs to the third, closely related, style of religion: the dynastic one.

\section{The Dynastic Style of Religion Among the Achaemenids}

A dynasty is, of course, basically a family and the evidence we have for family traditions - especially in the area of funerary arrangements - immediately shows this fact, alongside the fact that a dynasty is never an ordinary family. Momentous events in family life - birth, marriage, parenthood, bereavement, and death - have a particular acuteness for a ruling family, since they always have the potential to become matters of state concern. Similarly, celebrating festivals - one of the chief expressions of family religion throughout the ancient world - would almost naturally expand into state occasions whose symbolism speaks at least partly to the inner workings and cohesion of the empire.

The Achaemenids (like the Romans) did not have a coronation, although the late and singular testimony of Plutarch (Life of Artaxerxes 3; contrast Binder 2010 with de Jong 2010: pp. 545-547) suggests they had a certain (secret!) rite of investiture with an important religious element. The royal weddings are only described (in Greek sources) as festive occasions that were socially imposing, but did not have any religious component, and there is simply no information on rituals associated with birth (which would, at any rate, largely belong to the intimacy of family life). This leaves the rituals associated with the death of the king - or members of his family - as the most promising subject for an inquiry into dynastic religion. It is here, moreover, that the narrative sources of the Greek authors are to some extent confirmed by surviving material culture, and by the documentary evidence from Persepolis.

Arranging the funeral of a relative and honoring the souls of deceased relatives are important family duties throughout Iranian history. The evidence we have for royal burials is partly archeological - the tomb of Cyrus at Pasargadae and the tombs of various other kings at Persepolis and Naqsh-i Rustam - and partly literary (Briant 2002: pp. 522-523). These funerals were 
to be followed, however, by memorial services in honor of the deceased king and for these services we have literary evidence (de Jong 2010: pp. 533-534) and solid confirmation from the Elamite tablets (Henkelman 2003), both of which show that these duties, while rooted in family observance, were dynastic in nature. This is supported, moreover, by the fact that the ceremonies fell into desuetude with the downfall of the dynasty - with the resulting loss of all awareness of the Achaemenids in later Iranian historical tradition.

These funerary services are remarkably parallel to the institution of the regnal fire, the evidence for which is, however, regrettably slight. It is only the late Greek historian Diodorus Siculus (17.114.4) who mentions something resembling this institution, in the context of certain events that had taken place after Alexander's destruction of the Achaemenid empire (de Jong 2010: pp. 550-551). It has been suggested, very reasonably, that the custom of lighting a fire with the accession of the new king (known, at any rate, from the Parthian and Sasanian periods) was rooted in the family custom of lighting a householder's fire upon the founding of a new family (Boyce and Grenet 1991: p. 17). This fire, too, would be extinguished with the death of the father, just as Diodorus says that the sacred fires were extinguished upon the death of the king.

Similar fittingly elaborate forms of basic family observance can be seen in the descriptions of festivals and meals organized by the court, which can all be explained in terms of the "dynastic" style of religion, which marked the same occasions as family observance, but with a much larger audience and a greater symbolic weight. It is in this appropriately grand style of the practice of the religion that we can, moreover, locate most of the evidence for the integration of elements of an international dynastic style: the Achaemenid emulation of their Near Eastern predecessors.

\section{Conclusion}

The private lives of kings, including their private beliefs, fears, and rituals, are permanently hidden from sight. This is most often attributed to a lack of evidence, but it is unlikely that new evidence will ever turn up to mend this situation, since the dominant ideology of kingship entails the occlusion of the king as person. In some cases, the Achaemenid period can be shown to have been a period of transformation, but we can never succeed in isolating individual kings as motors of religious change. The same is true for the meaning religion may have had for any individual king. But quite apart from the intuition (and the evidence) that religion mattered to the Achaemenid kings, the combined evidence strikingly suggests that the Achaemenid kings mattered very much for the development of their religion. 


\section{REFERENCES}

Binder, S. (2010). Das Krönungszeremoniell der Achaimeniden. In B. Jacobs, R. Rollinger (eds.), Der Achämenidenhof - The Achaemenid Court (Classica et Orientalia 2). Wiesbaden: Harrassowitz, pp. 473-497.

Boyce, M., de Jong, A. (forthcoming). A History of Zoroastrianism IV: Parthian Zoroastrianism. Part I: Parthia and the Parthians. Leiden: Brill.

Boyce, M., Grenet, F. (1991). A History of Zoroastrianism III: Zoroastrianism under Macedonian and Roman Rule. Leiden: Brill.

Briant, P. (2002). From Cyrus to Alexander: A History of the Persian Empire. Winona Lake, IN: Eisenbrauns.

Henkelman, W. (2003). An Elamite memorial: the sumar of Cambyses and Hystaspes. In W. Henkelman, A. Kuhrt (eds.), A Persian Perspective: Essays in Memory of Heleen Sancisi-Weerdenburg (Achaemenid History 13). Leiden: Nederlands Instituut voor het Nabije Oosten, pp. 101-172.

Henkelman, W. (2008). The Other Gods Who Are: Studies in Elamite-Iranian Acculturation Based on the Persepolis Fortification Texts (Achaemenid History 14). Leiden: Nederlands Instituut voor het Nabije Oosten.

de Jong, A. (2010). Religion at the Achaemenid court. In B. Jacobs, R. Rollinger (eds.), Der Achämenidenhof - The Achaemenid Court (Classica et Orientalia 2). Wiesbaden: Harrassowitz, pp. 533-558.

de Jong, A. (2015). Religion and politics in pre-Islamic Iran. In M. Stausberg, Y. Vevaina (eds.), The Wiley Blackwell Companion to Zoroastrianism. Oxford: WileyBlackwell, pp. 85-101.

Kellens, J. (2002). L'idéologie religieuse des inscriptions achéménides. Journal Asiatique, 290, pp. 417-464.

Kellens, J. (2012). Les Achéménides et l'Avesta. In A. Agud (ed.), Séptimo Centenario de los Studies Orientalesen Salamanca. Salamanca: Ediciones Universidad Salamanca, pp. 551-558.

Knäpper, K. (2011). Die Religion der frühen Achaimeniden in ihrem Verbältnis zum Avesta. München: Herbert Utz Verlag.

Lincoln, B. (2012). 'Happiness for Mankind': Achaemenian Religion and the Imperial Project (Acta Iranica 53). Leuven: Peeters.

Nagel, B., Jacobs, B. (1989). Königsgötter und Sonnengottheit bei altiranischen Dynastien. Iranica Antiqua, 24, pp. 337-389.

Schmitt, R. (1982). Achaemenid throne-names. Annali dell'Istituto (Universitario) Orientale di Napoli, 42, pp. 83-95.

Skjaervø, P.O. (1999). Avestan quotations in old Persian? Literary sources of the old Persian inscriptions. In S. Shaked, A. Netzer (eds.), Irano-Judaica IV. Jerusalem: Ben Zvi Institute, pp. 1-64.

Skjaervø, P.O. (2012). The Zoroastrian oral tradition as reflected in texts. In A. Cantera (ed.), The Transmission of the Avesta (Iranica 20). Wiesbaden: Harrassowitz, pp. 3-48. 


\section{FURTHER READING}

Boyce, M. (1982). A History of Zoroastrianism II: Under the Achaemenians. Leiden: Brill. Influential but controversial overview of Achaemenid religion in the context of the long development of Zoroastrianism.

Henkelman, W. (2008). The Other Gods Who Are: Studies in Elamite-Iranian Acculturation Based on the Persepolis Fortification Texts (Achaemenid History 14). Leiden: Nederlands Instituut voor het Nabije Oosten. Groundbreaking study that aims to move beyond simple reconstructions of Achaemenid court life in the time of Darius by taking seriously the Elamite evidence.

Jacobs B., Rollinger R. (eds.) (2010). Der Achämenidenhof - The Achaemenid Court (Classica et Orientalia 2). Wiesbaden: Harrassowitz. Outstanding collection of articles on the Achaemenid court.

Lincoln, B. (2012). 'Happiness for Mankind': Achaemenian Religion and the Imperial Project. Leuven: Peeters. Provocative reconstruction of Achaemenid imperial ideology in thought, text, and practice. 